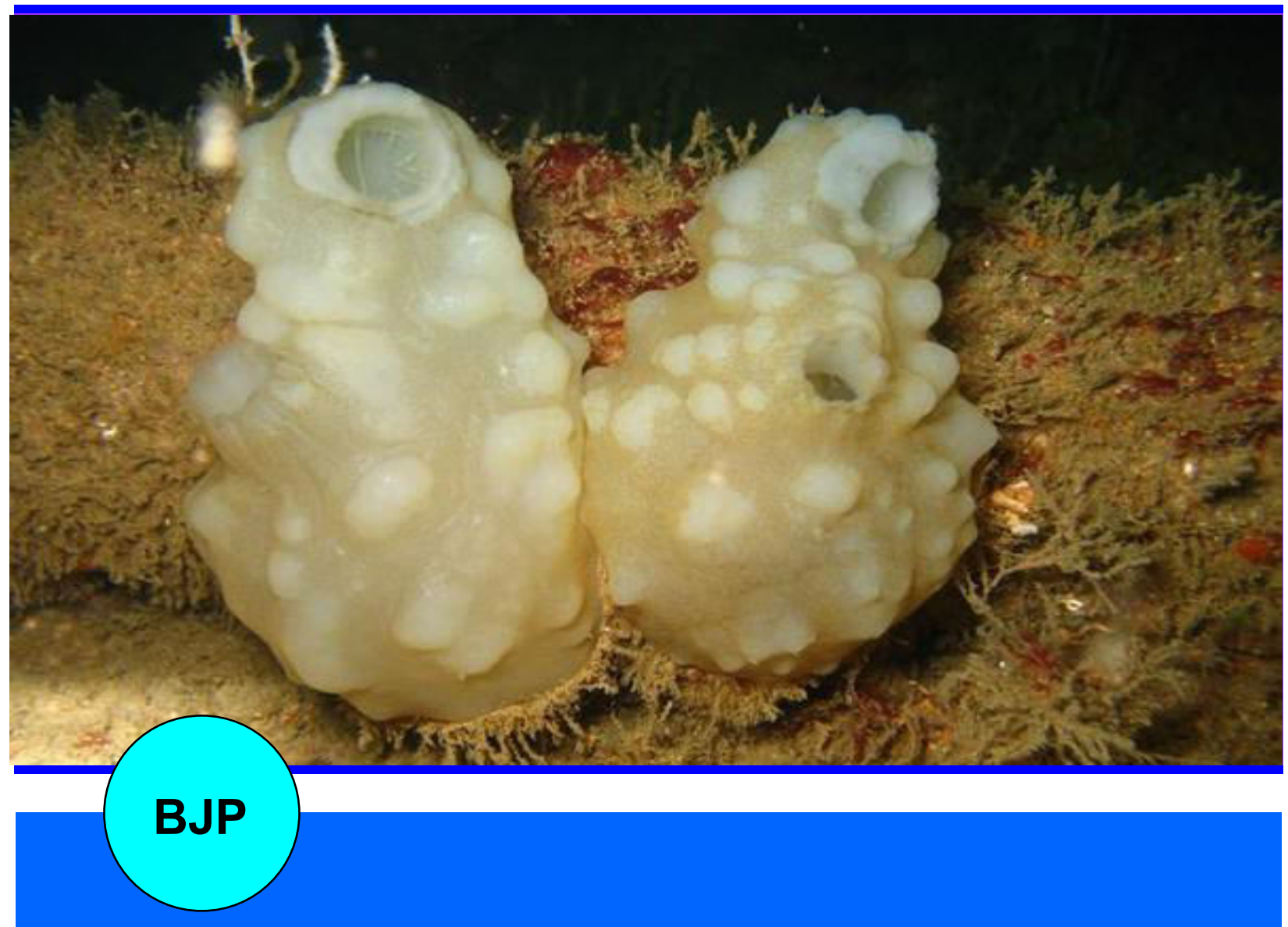

Bangladesh Journal of Pharmacology

Research Article

Alpha-amylase inhibitory activities of ascidians in the treatment of diabetes mellitus 


\title{
Alpha-amylase inhibitory activities of ascidians in the treatment of diabetes mellitus
}

\author{
Antonyraj Selva Prabhu and Gnanakkan Ananthan
}

CAS in Marine Biology, Faculty of Marine Sciences, Annamalai University, Parangipettai 608502, Tamil Nadu, India.

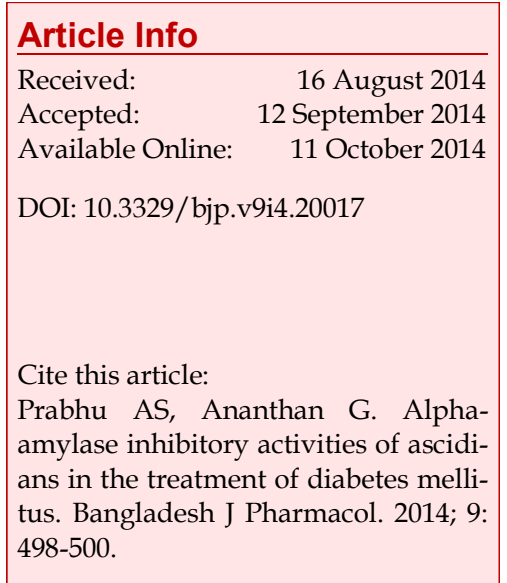

\section{Abstract}

Extracts of ten selected ascidians with a reputation of usefulness in treating diabetes were examined for alpha-amylase inhibition using an in vitro model. The extract with the highest activity was selected for further characterization. From the results ethyl acetate showed predominant amylase inhibition activity for all species and the maximum level of inhibition was recorded in Phallusia mammillata (68\%) at $300 \mu \mathrm{g} / \mathrm{mL}$ and the lowest activity was noted in Microcosmus squamiger $(12 \%)$ at $200 \mu \mathrm{g} / \mathrm{mL}$. After preliminary results, the methanolic extract of $P$. mammallita were further assayed for confirmation of enzyme inhibition and the maximum results (82\%) were obtained at $250 \mu \mathrm{g} /$ $\mathrm{mL}$ and the $\mathrm{IC}_{50}$ value of $P$. mammillata were evidenced at $145.0 \pm 0.4 \mu \mathrm{g} / \mathrm{g}$. In the present study, $P$. mammillata indicated the maximum a-amylase activity without toxic effects. Similarly, a-glucosidase and a-amylase inhibitor bromophenol, $\mathrm{C}_{6} \mathrm{H}_{5} \mathrm{BrO}$ was produced by $P$. mammillata.

\section{Introduction}

Type 2 diabetes is one of the primary threats to human health due to increasing prevalence, chronic course and disabling complications (Bhandari et al., 2008). Hence, retardation of starch digestion by inhibition of enzymes such as a-amylase plays a key role in the control of diabetes. Inhibitors of pancreatic a-amylase delay carbohydrate digestion causing a reduction in the rate of glucose absorption and lowering the post-prandial serum glucose levels (Chopra et al., 1986). Some inhibitors currently in clinical use are acarbose and miglitol which inhibit glycosidases such as $\beta$-glucosidase and $\alpha-$ amylase while others such as voglibose inhibit $\alpha-$ glucosidase. However, many of these synthetic hypoglycemic agents have their limitations, are non-specific, produce serious side effects and fail to alleviate diabetic complications.

The search for new pharmacologically active agents obtained by screening natural sources or their extracts can lead to potent and specific inhibitors for a-amylase (Grover et al., 2002). Pharmacological properties of aglucosidase inhibitors such as acarbose that can also inhibit pancreatic a-amylase revealed that the complications of diabetes mellitus such as onset of renal, retinal, lens and neurological changes and the development of ischemic myocardial lesions are prevented or delayed (Kotowaroo et al., 2006).

Long-term day-to-day management of diabetes, with acarbose is well tolerated and can improve glycaemic control as monotherapy, as well as in combination therapy (Kostova and Dinchev, 2005). The major adverse effects of acarbose are abdominal distention, flatulence, meteorism and possibly diarrhea (Klein et al., 2007). The search for safer, specific, and effective hypoglycemic agents has continued to be an important area of investigation with natural extracts from readily available traditional medicinal plants offering great potential for discovery of new anti-diabetic drugs (Klein et al., 2007). 


\section{Materials and Methods}

\section{Extraction}

The extraction of samples was carried out using the standard method (Pearce et al., 2007). The samples of freshly collected ascidians (Phallusia mammillata, $P$. arabica, Microcosmus squamiger, Microcosmus sp. Didemnum vexillum, Trididemnum savignii, Polyclinum aurantium, Polyclinum sp. Ascidia ahodori and Ascidia sp.) were kept in ice chest at $5^{\circ} \mathrm{C}$ and immediately transported to laboratory. After thorough cleaning, the samples were dissected and the mantle body was separated and freeze dried before being used. The freeze dried ascidian (150 g each) was separately extracted with methanol and acetone $(1 / 5, \mathrm{w} / \mathrm{v})$. The extracts were filtered and concentrated under vacuum on a rotary evaporator at $40^{\circ} \mathrm{C}$ to produce $9.96,10.2$ and $7.5 \mathrm{~g}$ of methanol extract, acetone extract and ethyl acetate extract respectively. The residues were further reconstituted in an appropriate buffer or normal saline for further assay.

\section{Extraction of a-amylase inhibitors}

$100 \mathrm{~g}$ of sample was dissolved in $300 \mathrm{~mL}$ of $0.2 \mathrm{M} \mathrm{NaCl}$ and kept for 1 hour at room temperature. After centrifugation at $17,400 \mathrm{rpm}$ for one hour, the supernatant was heated in boiling water bath at $80^{\circ} \mathrm{C}$ for 10 min and again centrifuged. The soluble material after heating is called heat soluble proteins. This material was subjected to ammonium sulfate precipitation. The fractions that precipitated at $0.5,1.0,1.5$ and $2.5 \mathrm{M}$ ammonium sulfate were designated as AS 0.5, 1.0, 1.5 and 2.5 respectively. Ammonium sulfate precipitates were suspended in $0.2 \mathrm{M}$ phosphate buffer ( $\mathrm{pH}$ 6.8) and dialyzed thoroughly against the same buffer for two days at $4^{\circ} \mathrm{C}$ (cold room). After centrifugation the supernatants were filtered through Whatman No. 1 filter paper. The filtrate was kept at $-20^{\circ} \mathrm{C}$ in a deep freezer and then lyophilized using lyodel lyophilizer. The buffer reconstituted $(10 \mathrm{mg} / 100 \mathrm{~mL})$ lyophilized powder was used as a source of a-amylase inhibitor for further studies.

\section{Enzyme and inhibitor assay}

One unit of a-amylase (diluted) and two mL (200 mg of partially purified inhibitor) of inhibitor sample to be assayed were mixed in $0.2 \mathrm{~mL}$ of $0.2 \mathrm{M}$ phosphate buffer ( $\mathrm{pH}$ 6.8) and incubated at $37^{\circ} \mathrm{C}$ for $15 \mathrm{~min}$, the reaction was stopped by adding $1 \mathrm{~mL}$ of DNSA reagent. According to the standard graph, drawn from different concentrations of enzymes, the maltose formed was calculated. One unit of enzyme activity was defined as the amount of enzyme causing the release of $1 \mu \mathrm{mol}$ of maltose in $1 \mathrm{~min}$ under the assay condition.

One inhibitor activity unit (I.U) was defined as the amount of inhibitor that caused $50 \%$ of inhibition of one unit of a-amylase enzyme.

\section{Results}

Ethyl acetate showed predominant amylase inhibition activity for all species and the maximum level of inhibition is recorded at $P$. mammillata $(68 \%)$ at $300 \mu \mathrm{g} /$ $\mathrm{mL}$ the lowest activity was noted in M. squamiger (12\%) at $200 \mu \mathrm{g} / \mathrm{mL}$ (Table I). The second predominant

\begin{tabular}{|c|c|c|c|c|c|c|c|c|c|}
\hline \multicolumn{10}{|c|}{ Table I } \\
\hline \multicolumn{10}{|c|}{ a-Amylase inhibition activity of different solvent extracts of Ascidians species } \\
\hline \multirow[t]{2}{*}{ Names } & \multicolumn{3}{|c|}{$\begin{array}{l}\text { \%Inhibition of methanol ex- } \\
\text { tracts }(\mu \mathrm{g} / \mathrm{mL})\end{array}$} & \multicolumn{3}{|c|}{$\begin{array}{l}\text { \%Inhibition of acetone extracts } \\
\qquad(\mu \mathrm{g} / \mathrm{mL})\end{array}$} & \multicolumn{3}{|c|}{$\begin{array}{l}\text { \%Inhibition of ethyl acetate ex- } \\
\text { tracts }(\mu \mathrm{g} / \mathrm{mL})\end{array}$} \\
\hline & 100 & 200 & 300 & 100 & 200 & 300 & 100 & 200 & 300 \\
\hline $\begin{array}{l}\text { Phallusia mam- } \\
\text { millata }\end{array}$ & $65 \pm 0.2$ & $78 \pm 0.0$ & $81 \pm 0.9$ & - & - & - & $40 \pm 0.7$ & $12 \pm 1.0$ & $35 \pm 0.0$ \\
\hline Phallusia arabica & $45 \pm 0.6$ & $65 \pm 0.7$ & $68 \pm 0.7$ & - & - & - & $45 \pm 0.6$ & $60 \pm 0.8$ & $65 \pm 0.1$ \\
\hline $\begin{array}{l}\text { Microcosmus } \\
\text { squamiger }\end{array}$ & $40 \pm 0.7$ & $60 \pm 0.4$ & $68 \pm 0.5$ & - & - & - & $65 \pm 0.2$ & $55 \pm 0.6$ & $68 \pm 0.0$ \\
\hline Microcosmus sp. & $48 \pm 0.1$ & $50 \pm 0.5$ & $60 \pm 1.2$ & $29 \pm 0.3$ & $50 \pm 0.6$ & $53 \pm 0.1$ & $48 \pm 0.0$ & $33 \pm 0.5$ & $57 \pm 0.9$ \\
\hline $\begin{array}{l}\text { Didemnum vexil- } \\
\text { lum }\end{array}$ & $48 \pm 0.6$ & $62 \pm 0.3$ & $74 \pm 0.1$ & - & - & - & $48 \pm 0.6$ & $54 \pm 0.3$ & $61 \pm 1.0$ \\
\hline $\begin{array}{l}\text { Trididemnum } \\
\text { savignii }\end{array}$ & - & - & - & - & - & - & - & $30 \pm 0.3$ & $53 \pm 0.6$ \\
\hline $\begin{array}{l}\text { Polyclinum au- } \\
\text { rantium }\end{array}$ & - & $4 \pm 0.2$ & $12 \pm 0.1$ & - & - & - & - & $52 \pm 0.3$ & $65 \pm 0.2$ \\
\hline Polyclinum sp. & - & - & - & - & - & - & $44 \pm 0.2$ & - & - \\
\hline Ascidia ahodori & $44 \pm 0.2$ & $63 \pm 0.3$ & $71 \pm 0.6$ & - & - & - & - & $29 \pm 0.5$ & $45 \pm 0.1$ \\
\hline Ascidia sp. & - & - & - & & & & $44 \pm 0.9$ & $52 \pm 0.6$ & $58 \pm 0.1$ \\
\hline
\end{tabular}




\begin{tabular}{|cc|}
\hline \multicolumn{2}{|c|}{ Table I } \\
\hline \multicolumn{2}{|c|}{ The maximum results of inhibition of Phallusia } \\
mammillata \\
\hline Concentration $(\mu \mathrm{g} / \mathrm{g})$ & Inhibition $(\%)$ \\
\hline 16 & $8 \pm 0.0$ \\
31.3 & $13 \pm 0.2$ \\
62.5 & $28 \pm 0.8$ \\
125 & $45 \pm 0.4$ \\
250 & $82 \pm 0.2$ \\
$\mathrm{IC}_{50}$ & $145 \pm 0.4$ \\
\hline
\end{tabular}

inhibition activity was observed in methanol extracts and showed superior activity for 9 species except $T$. savignii and the maximum activity was noted in $P$. mammillata $(81 \%)$ at $300 \mu \mathrm{g} / \mathrm{mL}$ and the least activity is noted in $P$. aurantium at $200 \mu \mathrm{g} / \mathrm{mL}$. Very poor amylase inhibition activity is recorded in acetone extracts and only Microcosmus sp. showed inhibition activity (53\%) at $200 \mu \mathrm{g} / \mathrm{mL}$ and the other 9 ascidian species failed to display any results. From the above results, the premier enzyme inhibition results were recorded in methanolic extract of $P$. mammallita at $300 \mu \mathrm{g} / \mathrm{mL}$. After prelimnary results, the methanolic extract of $P$. mammallita was further assayed for confirmation of enzyme inhibition and the results are shown in Table II. The maximum results were obtained $(82 \%)$ at $250 \mu \mathrm{g} / \mathrm{mL}$ and the $\mathrm{IC}_{50}$ value of $P$. mammillata were evidenced at $145 \pm 0.4 \mu \mathrm{g} / \mathrm{g}$.

\section{Discussion}

In the present study, P. mammillata indicated the maximum a-amylase activity without toxic effects. Similarly, a-glucosidase and a-amylase inhibitor bromophenol, $\mathrm{C}_{6} \mathrm{H}_{5} \mathrm{BrO}$, is produced by $P$. mammillata. It has been used in the therapy of type II diabetes mellitus, in order to enable patients to control blood sugar contents while living with starch-containing diets. Other species of ascidians also produce various other components which inhibit a-glucosidase and a-amylase, of which compo- nent is hard to separate during extraction and purification, which is one of the most modern work-up processes developed to date (Kim et al., 2010).

\section{Acknowledgements}

Authors are grateful to the Ministry of Environment and Forests, Government of India for providing financial assistance to undertake the study, Dean and Director, CAS in Marine Biology, Faculty of Marine Sciences and Authorities of Annamalai University for providing the facilities to carry out the research project.

\section{References}

Bhandari MR, Jong-Anurakkun N, Hong G, Kawabata J. aGlucosidase and a-amylase inhibitory activities of Nepalese medicinal herb Pakhanbhed (Bergenia ciliata, Haw.). Food Chem. 2008; 106: 247-52.

Chopra RN, Nayar SL, Chopra IC. Glossary of Indian medicinal plants. Council of Scientific and Industrial Research, New Delhi, India, 1986.

Kim K, Himmeldirk Y, Chen X. Evidence-based complementary and alternative medicine. J Mol Biol. 2007; 4: 401-07.

Klein G, Kim J, Himmeldirk K, Cao Y, Chen X. Evidence-based complementary and alternative medicine. J Mol Biol. 2007; 4: 401-07.

Kostova I, Dinchev D. Saponins in Tribulus terrestris: Chemistry and bioactivity. Phytochem Rev. 2005; 4: 111-37.

Kotowaroo MI, Mahomoodally MF, Gurib-Fakim A, Subratty AH. Traditional medicinal herbs and food plants have the potential to inhibit key carbohydrate hydrolyzing enzymes in vitro and reduce postprandial blood glucose peaks in vivo. Phytothera Res. 2006; 20: 228-31.

Pearce AN, Chia EW, Berridge MV, Clark GR, Harper JL, Larsen L, Maas EW, Page MJ, Perry NB, Webb VL, Copp BR. Anti-inflammatory Thiazine Alkaloids Isolated from the New Zealand ascidian Aplidium sp. Inhibitors of the neutrophil respiratory burst in a model of gouty arthritis. J Nat Products. 2007; 70: 111-13. 